\title{
PENGEMBANGAN MODUL FISIKA BERBASIS LEARNING CYCLE 5E UNTUK MENINGKATKAN KEMAMPUAN BERPIKIR ANALITIS SISWA
}

\author{
Farida Hannum ${ }^{1}$, Sukarmin ${ }^{2}$, Cari $^{3}$ \\ ${ }^{1}$ Program Studi Magister Pendidikan Sains FKIP Universitas Sebelas Maret \\ Surakarta, 57126, Indonesia \\ faridahannum8@gmail.com \\ ${ }^{2}$ Program Studi Magister Pendidikan Sains FKIP Universitas Sebelas Maret \\ Surakarta, 57126, Indonesia \\ sukarmin@staff.uns.ac.id \\ ${ }^{3}$ Program Studi Magister Pendidikan Sains FKIP Universitas Sebelas Maret \\ Surakarta, 57126, Indonesia \\ cari@staff.uns.ac.id
}

\begin{abstract}
Abstrak
Latar belakang penelitian ini adalah karena keterbatasan bahan ajar yang sesuai dengan kebutuhan pembelajaran bagi siswa dan guru. Penelitian ini bertujuan untuk: (1) mendeskripsikan karakteristik modul pembelajaran fisika berbasis Learning Cycle 5E, (2) mengetahui kelayakan modul, (3) mengetahui efektivitas penggunaan modul terhadap kemampuan berpikir analitis dan hasil belajar siswa. Metode penelitian yang digunakan Research and Development (R\&D) dengan model 4-D yang terdiri dari: (1) define, (2) design, (3) develop, dan (4) disseminate. Materi yang dikembangkan dalam modul adalah Fluida Statis yang diperuntukkan siswa SMA kelas XI IPA. Modul yang dikembangkan divalidasi oleh ahli materi, ahli bahasa, ahli media, reviewer, dan peer review. Modul dikategorikan layak untuk implementasikan. Modul diujicobakan secara terbatas pada 12 siswa di SMA Negeri 2 Ngawi dan diperoleh hasil bahwa modul termasuk dalam kategori "Sangat Baik" menurut siswa. Modul diujicoba dalam skala besar pada siswa kelas XI SMA Negeri 2 Ngawi. Data yang diperoleh yaitu data kemampuan berpikir analitis dan hasil belajar. Berdasarkan hasil penelitian dan pengembangan disimpulkan bahwa: (1) karakteristik modul fisika yang dikembangkan berupa modul cetak materi fluida statis yang berbasis Learning Cycle 5E dengan tahapan engage, explore, explain, elaborate, dan evaluate dengan memunculkan indikator kemampuan berpikir analitis dalam setiap tahapannya yaitu menginterpretasi informasi, menggunakan konsep dalam pemecahan masalah, membuat dan mengevaluasi kesimpulan, serta memberikan alasan setiap jawaban, (2) modul pembelajaran fisika berbasis Learning Cycle 5E yang dikembangkan layak karena memenuhi kriteria nilai kelayakan berdasarkan Cut Off Score yaitu sebesar $87,32 \%$, respon guru dalam tahap penyebaran sebesar $84,00 \%$ dalam kategori sangat baik, dan hasil angket respon modul oleh siswa sebesar 80,62\% dalam kategori sangat baik, (3) modul pembelajaran fisika berbasis Learning Cycle 5E efektif dalam meningkatkan kemampuan berpikir analitis serta ketercapaian ketuntasan hasil belajar siswa. Nilai rata-rata kemampuan berpikir analitis siswa sebesar 0,41 yang termasuk kategori "Sedang". Sedangkan rata-rata ketuntasan hasil belajar siswa sebesar 87,50\% meningkat melampaui KKM.
\end{abstract}

Kata Kunci : Modul Fisika, Learning Cycle 5E, Kemampuan Berpikir Analitis

\section{Pendahuluan}

Sains atau fisika merupakan ilmu pengetahuan tentang gejala alam yang dituangkan berupa fakta, konsep, prinsip dan hukum yang teruji kebenarannya dan melalui suatu rangkaian kegiatan dalam metode ilmiah (Suparno, 2007). Pembelajaran Fisika dikembangkan dengan mengacu pada 
kemampuan observasi atau pengamatan dan kemampuan eksperimentasi atau percobaan. Menurut Indrianto (2014) banyak ditemukan kendala-kendala dalam pembelajaran sains, yaitu faktor internal dan eksternal. Faktor internal adalah masalah yang timbul dari dalam diri siswa yang bersifat biologis dan psikologis. Masalah yang bersifat psikologis merupakan masalah yang bersifat psikis seperti, motivasi, perhatian, minat, emosi, dan mental. Faktor eksternal adalah masalahmasalah yang timbul dari luar diri siswa yaitu, sarana belajar, suasana belajar, media, dan sumber belajar. Inilah mengapa pengembangan media pembelajaran dianggap besar pengaruhnya untuk pembelajaran sains.

Kemampuan berpikir terutama kemampuan berpikir tingkat tinggi menurut Archer (2001) dalam Zulfah (2015:1) merupakan kemampuan yang sangat esensial untuk kehidupan dan mempengaruhi keberhasilan hidup karena menyangkut yang dikerjakan dan dihasilkan individu, sehingga kemampuan berpikir memiliki peranan yang penting dalam pengembangan sikap dan persepsi yang mendukung terciptanya kondisi kelas yang positif, memperoleh, dan mengintegrasi pengetahuan, memperluas wawasan pengetahuan, mengaktualisasikan kebermaknaan pengetahuan, dan mengembangkan perilaku berpikir yang menguntungkan. Kemampuan berpikir tingkat tinggi dapat diberdayakan, salah satunya melalui pengembangan aspek kemampuan analisisnya.

Kemampuan berpikir analisis merupakan suatu kemampuan dasar yang harus dimiliki oleh siswa. Kemampuan berpikir analitis dapat diperoleh siswa melalui penerapan pembelajaran yang inovatif, konstruktifistik, kreatif dan mampu mengajak siswa membangun pemahaman terhadap konsep yang dipelajari. Kemampuan berpikir analitis ini sangat erat kaitannya dengan teori konstruktivis yang mengoptimalkan kemampuan siswa untuk menemukan dan membangun pemahaman terhadap konsep pengetahuannya sendiri (Thaneerananon, 2016). Menurut Areesophonpichet (2013), kemampuan berpikir analitis adalah kemampuan berpikir siswa untuk menguraikan, memperinci, dan menganalitis informasi-informasi yang digunakan untuk memahami suatu pengetahuan dengan menggunakan akal dan pikiran yang logis, bukan berdasar perasaan atau tebakan. Untuk dapat berpikir analitis diperlukan kemampuan berpikir logis dalam mengambil kesimpulan terhadap suatu situasi. Kemampuan berpikir analisis yang dilatihkan dalam pembelajaran fisika akan menyebabkan siswa memiliki kemampuan berpikir kritis dalam memecahkan suatu permasalahan (Erniningsih, 2012: 2). Dengan demikian kemampuan berpikir analisis perlu dilatihkan dalam pembelajaran fisika, karena dalam pembelajaran fisika siswa tidak hanya menghafalkan rumus-rumus ataupun teori akan tetapi siswa akan dihadapkan dengan permasalahan yang membutuhkan analisis

Hasil observasi di SMA Negeri 2 Ngawi dan wawancara dengan guru mata pelajaran fisika diperoleh informasi mengenai permasalahanpermasalahan yang dihadapi dalam proses pembelajaran yaitu: 1) pembelajaran masih bersifat teacher centered sehingga proses pembelajaran masih bersifat satu arah; 2) kurangnya interaksi antara guru dengan siswa sehingga siswa cendurung pasif ketika pembelajaran berlangsung; 3) kurangnya kegiatan penyelidikan ilmiah berupa kegiatan percobaan yang mengarahkan siswa untuk belajar dengan cara menemukan sendiri konsep yang sedang dipelajarai mengakibatkan rendahnya pemahaman konsep siswa; 4) kemampuan berpikir analitis siswa 
masih tergolong rendah karena selama pembelajaran siswa kurang terfasilitasi untuk mengembangkan kemampuan berpikir analisisnya; 5) model dan media pembelajaran yang digunakan kurang bervariasi mengakibatkan rendahnya hasil belajar siswa.

Berdasarkan analisis kebutuhan siswa, sebanyak $72,22 \%$ siswa menyatakan tertarik untuk belajar fisika menggunakan model pembelajaran Learning Cycle 5E. Hal ini diperkuat dengan komentar siswa bahwa mereka lebih menyukai pembelajaran yang diawali dengan fenomena fisis yang dapat mereka temui dalam kehidupan sehari-hari, kemudian melakukan penyelidikan untuk membangungan konsep dari fenomena fisis itu secara mandiri. Diperoleh juga informasi dari analisis kebutuhan bahwa sebanyak $75 \%$ siswa menyatakan butuh bahan ajar alternatif yang lebih menarik, terperinci, dan berisi dengan contoh aplikasi dalam keseharian. Sehingga sebanyak 82,86\% siswa menyatakan tertarik untuk belajar fisika menggunakan modul.

Berdasarkan hasil wawancara dan angket kebutuhan guru fisika di SMA Negeri 2 Ngawi diperoleh informasi bahwa $75 \%$ guru menyatakan buku fisika yang digunakan di sekolah masih memiliki kekurangan. Adapun kekurangannya yaitu pada segi kelengkapan pemaparan materi, penyajian aplikasi suatu konsep fisika dalam bidang teknologi, masih kurang mengutamakan kegiatan proses sains, dan tampilannya dinilai kurang menarik. Hasil analisis kebutuhan guru menunjukkan bahwa $86 \%$ guru tertarik untuk menggunakan bahan ajar berupa modul. Modul yang dibutuhkan guru adalah modul yang berisi tentang penjelasan konsep, aplikasi konsep, serta kegiatan laboratorium yang mampu mengembangkan kemampuan berpikir analisis siswa. Hal ini didasari dari hasil wawancara dengan guru yang menyatakan bahwa kemampuan berpikir tingkat tinggi siswa SMA Negeri 2 Ngawi kurang berkembang, salah satunya adalah kemampuan analisis siswa. Menurut guru, keadaan ini disebabkan karena selama ini siswa belum terlatih untuk berpikir secara analisis, diperkuat dengan media pembelajaran yang ada belum maksimal untuk mengarahkan siswa menganalisis dan mengkontruksi konsep fisika. Sehingga guru membutuhkan bahan ajar alternatif yang dapat mengatasi kondisi tersebut

Berdasarkan hasil observasi, wawancara, dan analisis kebutuhan dapat disimpulkan bahwa diperlukan pengembangan bahan ajar yang konten materinya lengkap, menarik, menyajikan permasalahan fisika dalam kehidupan sehari-hari, mengarahkan siswa untuk menemukan konsepnya sendiri, dan mampu melibatkan siswa secara aktif dalam kegiatan pembelajaran. Solusi yang ditawarkan untuk memenuhi ketersediaan bahan ajar adalah dengan mengembangkan modul. Modul dijadikan pilihan karena beberapa kelebihan diantaranya: 1) sebagai sumber belajar yang dapat dipelajari secara mandiri sehingga siswa dapat mempelajarinya kapanpun dan dimanapun ia kehendaki; 2) mengurangi pembelajaran yang berpusat pada guru; 3) siswa dapat berinteraksi dengan aktif karena harus merespon terhadap pertanyaan dan latihan dalam modul; 4) dalam penyajiannya modul menggunakan bahasa yang sederhana dan komunikatif sehingga memudahkan siswa dalam mempelajarinya.

Materi yang dipilih dalam penelitian ini adalah materi fluida statis. Pemilihan materi fluida statis ini didasarkan pada hasil nilai ujian nasional tahun pelajaran 2013/2014 dan 2014/2015 yang diterbitkan oleh Balai Penelitian Pendidikan Badan Penelitian dan Pengembangan Kementrian Pendidikan dan Kebudayaan menunjukkan bahwa daya serap siswa 
SMA Negeri 2 Ngawi pada materi fluida statis masih rendah apabila dibandingkan dengan daya serap tingkat kabupaten dan propinsi. Pada tahun pelajaran 2013/2014 daya serap tingkat sekolah sebesar $70,00 \%$, daya serap siswa tingkat kabupaten Ngawi sebesar $72,74 \%$, dan tingkat provinsi Jawa Timur sebesar 79,62\%. Daya serap siswa SMA Negeri 2 Ngawi pada materi fluida statis di tahun pelajaran 2014/2015, pada tingkat sekolah sebesar $64,35 \%$, lebih rendah dari daya serap tingkat kabupaten yang sebesar $66,54 \%$ dan daya serap tingkat provinsi yang sebesar $72,71 \%$. Daya serap siswa SMA Negeri 2 Ngawi pada materi fluida juga masih tergolong rendah apabila dibandingkan dengan daya serap siswa pada materi lain yang prosentase daya serapnya antara $73-84 \%$ seperti pada materi fisika modern, dinamika dan perubahan energi, kinematika, suhu, kalor, dan hukum termodinamika, serta gelombang, bunyi, dan cahaya. Sehingga dapat dikatakan bahwa siswa masih mengalami kesulitan dalam memahami materi fluida statis.

Jauhariyah (2013) menyatakan bahwa materi fluida dalam pembelajaran mempunyai karakteristik materi yang dapat disampaikan dengan konsep pembelajaran yang konkrit agar mudah dipahami siswa. Sesuai karakteristiknya, materi ini banyak ditemukan dalam kehidupan sehari-hari, sehingga banyak sekali permasalahan yang berhubungan dengan fluida yang dapat dijadikan acuan dalam pembelajaran. Dari temuan permasalahan tersebut, akan lebih baik apabila siswa mampu menemukan jawaban dari permasalahan tersebut dan membangun sendiri pemahaman konsepnya. Pembelajaran akan lebih bermakna dan informasi yang didapatkan akan bertahan lebih lama jika ada kaitan antara konsepsi awal siswa dengan konsep baru yang sedang dipelajari.
Proses pembelajaran akan lebih bermakna dan informasi yang didapatkan akan bertahan lebih lama, jika ada kaitan antara konsepsi awal siswa dengan konsep baru yang sedang dipelajari, hal ini sesuai dengan pandangan konstruktivisme (Dahar, 1989). Konstruktivisme merupakan salah satu filsafat pengetahuan yang menekankan bahwa pengetahuan siswa adalah konstruksi bentukan siswa sendiri (Prastowo, 2013). Hal ini senada seperti yang diungkapkan oleh Suparno (2013) bahwa dalam teori konstruktivisme, siswa membangun sendiri pengetahuan melalui pengalaman yang diperoleh.

Model pembelajaran Learning Cycle 5E merupakan salah satu model pembelajaran yang menganut teori konstruktivisme. Learning Cycle adalah suatu model pembelajaran yang berpusat pada siswa (student centered) yang merupakan rangkaian tahap-tahap kegiatan yang diorganisasi sedemikian rupa sehingga siswa dapat menguasai kompetensi yang harus dicapai dalam pembelajaran dengan berperan aktif (Taufiq, 2010). Hal ini senada dengan Permatasari (2015) yang menyatakan bahwa model pembelajaran siklus belajar (Learning Cycle) adalah model pembelajaran yang mengarahkan siswa menemukan dan memperoleh pengetahuan baru. Model tersebut akan membuat siswa menjadi kompeten dalam berbagai aspek, baik pengetahuan, sikap, dan ketrampilan dalam pembelajaran.

Model Learning Cycle 5E adalah model pembelajaran yang terdiri fase-fase atau tahap-tahap kegiatan yang diorganisasikan sedemikian rupa sehingga siswa dapat menguasai kompetensi-kompetensi yang harus dicapai dalam pembelajaran dengan jalan berperan aktif (Campbell, 2006: 14). Model pembelajaran Learning Cycle 5E ini mempunyai salah satu tujuan yaitu memberikan kesempatan kepada siswa untuk mengkonstruksi 
pengetahuan dan pengalaman mereka sendiri dengan terlibat secara aktif mempelajari materi secara bermakna dengan bekerja dan berfikir baik secara individu maupun kelompok, sehingga siswa dapat menguasai kompetensikompetensi yang harus dicapai dalam pembelajaran. Siklus belajar yang digunakan dalam rencana pembelajaran terdapat lima langkah, yaitu Engage (Menarik perhatian), Explore (Menyelidiki), Explain (Menjelaskan), Elaborate (Menerapkan), dan Evaluate (Mengevaluasi). Setiap siklus, benarbenar ada proses akhir. Setelah berakhir elaborasi, keterlibatan siklus belajar berikutnya dimulai. Evaluasi bukan langkah terakhir. Evaluasi terjadi dalam semua empat bagian dari siklus belajar (Bybee, 2009). Kelebihan dari model pembelajaran Learning Cycle 5E menurut Lorbach dalam Misman (2013) diantaranya; 1) memberikan motivasi dan menambah keingintahuan siswa; 2) melatih siswa belajar menemukan konsep melalui kegiatan eksperimen; 3) melatih siswa menyampaikan secara lisan konsep yang telah mereka pelajari; dan 4) membantu meningkatkan keterampilan analitis siswa karena memberikan kesempatan kepada siswa untuk berfikir, mencari, menemukan, dan menjelaskan konsep yang mereka pelajari.

Berdasarkan pemaparan di atas, penulis mencoba untuk melakukan penelitian pengembangan modul fisika berbasis Learning Cycle 5E untuk meningkatkan kemampuan berpikir analitis siswa pada materi fluida statis di SMA Negeri 2 Ngawi. Implementasi modul pembelajaran berbasis Learning Cycle 5E membantu siswa untuk menemukan dan membangun pengetahuan siswa melalui aktivitas penyelidikan ilmiah yang mampu mengembangkan kemampuan berpikir analitis. Sehingga pada akhirnya dapat berpengaruh positif terhadap ketercapaian ketuntasan hasil belajar siswa.

Penelitian ini bertujuan untuk: 1) mendeskripsikan karakteristik modul pembelajaran fisika berbasis Learning Cycle 5E untuk meningkatkan kemampuan berpikir analitis siswa; 2) mengetahui kelayakan modul pembelajaran fisika berbasis Learning Cycle 5E untuk meningkatkan kemampuan berpikir analitis siswa; 3) mengetahui efektivitas penggunaan modul pembelajaran fisika berbasis Learning Cycle 5E terhadap kemampuan berpikir analitis dan hasil belajar siswa.

\section{Metode Penelitian}

Metode penelitian yang digunakan yaitu penelitian dan pengembangan (research and development). Model yang digunakan sebagai dasar untuk mengembangkan modul fisika berbasis Learning Cycle 5E ini hasil adaptasi model 4-D (four- $D$ model) yang dikemukakan oleh Thiagarajan, dkk (1974) yang meliputi proses define, design, develop, dan disseminate.

Teknik analisis data untuk data analisis kebutuhan menggunakan teknik deskriptif kualitatif dimana hasil pendiskripsian data hasil analisis kebutuhan digunakan untuk keperluan pertimbangan pengembangan modul fisika berbasis Learning Cycle 5E. Untuk mengetahui kesimpulan hasil uji validitas media, materi, bahasa, guru dan teman sejawat, digunakan metode cut off score (skor batas bawah) Tam \& al (2001) dalam Septiani (2009).

cut off point $=\frac{\text { (skor maksimum }- \text { skor minimum) }}{2}$

Teknik analisis data kemampuan berpikir analitis siswa menggunakan ujit sampel berpasangan dan uji $\mathrm{N}$-Gain ternormalisasi. Namun sebelumnya dilakukan uji prasyarat yaitu uji normalitas dan homogenitas data. Hasil 
belajar yang diukur meliputi 3 ranah yaitu kognitif, afektif, dan psikomotor. Hasil belajar kognitif diperoleh berdasarkan hasil tes kognitif. Sedangkan hasil belajar ranah afektif dan psikomotor didapatkan dari hasil observasi selama pembelajaran. Efektivitas modul terhadap hasil belajar dilihat berdasarkan ketercapaian KKM sebesar 75 dan prosentase ketuntasan minimal $75 \%$.

\section{Hasil Penelitian dan Pembahasan}

Model yang digunakan sebagai dasar untuk mengembangkan modul fisika berbasis Learning Cycle 5E ini merupakan hasil adaptasi model 4-D (four-D model) yang dikemukakan oleh Thiagarajan, dkk (1974) dalam yang meliputi proses define, design, develop, dan disseminate. Penelitian pengembangan ini menunjukkan hasil sebagai berikut :

\section{Tahap Pendefinisian (Define)}

Tahap ini merupakan tahapan untuk mengidentifikasi masalah-masalah yang ada dalam proses pembelajaran dan menjadi dasar untuk merancang produk berupa modul yang dibuat. Pada tahapan ini dilakukan analisis kebutuhan siswa dan analisis kebutuhan guru dalam pembelajaran.

Analisis kebutuhan siswa dilakukan terhadap 30 siswa di SMA Negeri 2 Ngawi. Data yang dihasilkan antara lain kecenderungan siswa untuk belajar kelompok $83,33 \%$ dibandingkan dengan belajar secara mandiri $26,67 \%$. Sebanyak $72,22 \%$ siswa menyatakan tertarik untuk belajar fisika menggunakan model pembelajaran Learning Cycle 5E. Didapatkan pula data ketersediaan bahan ajar untuk siswa sebesar 66,67\% dengan kebutuhan bahan ajar sebesar $75,00 \%$. Selain itu sebanyak $82,86 \%$ siswa menyatakan tertarik untuk belajar menggunakan modul. $\begin{array}{ccc}\text { Analisis } & \text { kebutuhan } & \text { siswa } \\ \text { menunjukkan } & \text { bahwa } & \text { siswa }\end{array}$ membutuhkan bahan ajar yang lebih lengkap dan menarik jika dibandingkan dengan bahan ajar yang mereka dapat dari sekolah. Kurang lengkapnya bahan ajar yang dimiliki membuat siswa juga menggunakan bahan ajar lain dari luar untuk menunjang kebutuhan belajar mereka. Tentunya hal ini menjadi salah satu hambatan siswa dalam belajar. Definisi lengkap menurut siswa adalah bahan ajar yang tidak hanya menguraikan materi secara mendalam tetapi juga dilengkapi dengan banyak aplikasi konsep fisika yang dapat mereka temui dalam kehidupan seharihari. Siswa menyatakan bahwa mereka menemukan fenomena fisika dalam kehidupan sehari-hari tetapi siswa belum dapat memahami bagaimana konsep fisika bekerja pada fenomena tersebut. Oleh karena itu, dibutuhkan suatu bahan ajar yang didalamnya disajikan permasahan dan kegiatan penyelidikan ilmiah untuk mencari solusi dari permasalahan yang ada. Kegiatan ini dapat berupa kegiatan praktikum sederhana. Menurut siswa adanya banyak kegiatan percobaaan akan membuat mereka lebih tertarik untuk mempelajari fisika karena mereka bisa menemukan sendiri jawaban dari permasalahan yang ditampilkan. Sehingga konsep yang sedang dipelajari akan lebih terekam dalam memori. Salah satu model pembelajaran yang diawali dengan penyajian masalah kemudian mengarahkan siswa untuk menemukan jawaban permasalahannya sendiri adalah pembelajaran berbasis konstruktivisme. Salah satu model pembelajaran yang berbasis konstruktivisme adalah model pembelajaran Learning Cycle 5E. Sehingga, dapat disimpulkan bahwa siswa membutuhkan bahan ajar fisika alternatif yaitu modul pembelajaran fisika berbasis Learning Cycle 5E.

Analisis kebutuhan guru dilakukan menggunakan bantuan angket 
INKUIRI: Jurnal Pendidikan IPA

Vol. 8, No. 1, 2019 (hal 94-109)

https://jurnal.uns.ac.id/inkuiri

kebutuhan guru dan dilakukan terhadap 4 guru fisika di SMA Negeri 2 Ngawi. Hasil analisis kebutuhan antara lain menunjukkan bahwa $75 \%$ guru menyatakan kurangnya ketersediaan bahan ajar dalam hal kelengkapan pemaparan materi, teknik penjelas, beserta contoh aplikasi konsep pada buku yang disediakan sekolah, sehingga guru menggunakan buku lain sebagai pelengkap dan penunjang dalam mengajar. Didapatkan pula data sebanyak $88 \%$ guru menyatakan membutuhkan bahan ajar penunjang lainnya. Selain itu sebanyak $86 \%$ guru tertarik dikembangkan media alternatif berupa modul karena pengalaman guru yang pernah menggunakan modul hanya $33 \%$. Hasil analisis angket menunjukkan bahwa pembelajaran di kelas belum bersifat student oriented, guru lebih dominan dalam proses pembelajaran dibandingkan dengan siswa. Sesekali guru mengawali proses pembelajaran dengan sebuah masalah fisika yang dapat siswa amati dalam kehidupan sehari-hari. Akan tetapi, siswa belum diarahkan secara optimal untuk mengembangkan kemampuan berpikir analitisnya dalam menyelesaikan permasalahan fisika yang bersifat konseptual. Menurut guru, level kemampuan berpikir analitis siswa di SMA Negeri 2 Ngawi secara umum tergolong dalam kategori sedang dan rendah. Guru menyatakan bahwa kurangnya kesempatan siswa untuk dilatih berpikir analitis menyebabkan kemampuan analitis siswa cendurung rendah. Guru menyatakan bahwa untuk dapat melatih siswa berpikir analitis maka pembelajaran fisika dapat ditunjang melalui kegiatan praktikum. Dari kegiatan praktikum ini siswa dapat berlatih untuk menemukan, berpikir, dan menganalisis konsep secara mandiri untuk menjawab permasalahan yang diajukan.

Terkait dengan penerapan model pembelajaran, guru menyatakan bahwa
P-ISSN: 2252-7893

E-ISSN: 2615-7489

DOI: 10.20961/inkuiri.v8i1.31824

belum pernah menerapkan model pembelajaran Learning Cycle 5E. Sehingga guru merasa perlu menggunakan model pembelajaran ini untuk mengetahui respon siswa. Agar dapat menerapkan model pembelajaran berbasis Learning Cycle 5E dikelas dengan tepat pada materi fluida statis, guru memerlukan suatu bahan ajar yang didalamnya memuat unsur-unsur pembelajaran berbasis Learning Cycle 5E. Oleh karena itu, guru tertarik dengan adanya pengembangan modul fisika berbasis Learning Cycle 5E pada materi fluida statis.

Analisis penguasaan materi fluida statis pada UN tahun 2013/2014 untuk tingkat sekolah sebesar 70,00\%; kabupaten $72,74 \%$; provinsi $79,62 \%$; dan nasional $61,68 \%$. Hasil presentase penguasaa materi fluida statis justru turun pada UN tahun 2014/2015, yaitu untuk lingkup sekolah sebesar $64,35 \%$; kabupaten $66,54 \%$; provinsi $72,71 \%$; dan nasional $66,75 \%$. Penguasaan materi fluida statis masih tergolong cukup rendah apabila dibandingkan dengan materi lain seperti fisika modern, dinamika dan perubahan energi, kinematika gerak, suhu, kalor, dan termodinamika, gelombang, bunyi, serta cahaya. Rendahnya daya serap pada materi fluida statis ini disebabkan karena guru kurang melibatkan siswa saat proses pembelajaran sehingga siswa kurang terlatih untuk membangun pengetahuannya sendiri melalui pengalaman belajar. Menurut Permatasari (2015:66) menyatakan bahwa pengalaman belajar akan membuat siswa lebih mudah mengingat apa yang mereka pelajari. Rendahnya daya serap siswa juga disebabkan karena kurangnya ketersediaan bahan ajar di sekolah yang sesuai dengan karakteristik dan kebutuhan belajar siswa khususnya untuk materi fluida statis.

Berdasarkan hasil analisis kebutuhan siswa, guru, dan materi, maka dapat disimpulkan bahwa perlu adanya 
pengembangan media alternatif modul. Pada materi fluida statis. Basis modul yang digunakan adalah Learning Cycle 5E karena model pembelajaran ini mengarahkan siswa untuk menemukan konsep dari fenomena/ kejadian di sekitar yang sering ditemukan siswa kemudian siswa membentuk konsepnya sendiri dari hasil penelitian. Tujuan pembuatan modul ini adalah untuk meningkatkan kemampuan berpikir analitis siswa, hal ini dimaksudkan untuk mengatasi kurangnya kemampuan siswa dalam berpikir tingkat tinggi analitis seperti yang sudah diungkapkan guru sebelumnya.

\section{Tahap Perancangan (Design)}

Modul yang dikembangkan terdiri dari tiga bagian utama yaitu pendahuluan, isi, dan penutup. Format modul ini disesuaikan dengan format yang disarankan oleh Depdiknas (2008). Bagian pendahuluan terdiri dari bagian judul, halaman francis, kata pengantar, daftar isi, pendahuluan modul yang menampilkan tentang deskripsi modul, komponen utama, komponen pendukung, komponen yang ingin ditinjau dalam modul, petunjuk penggunaan modul, prasyarat, peta konsep, dan tujuan pembelajaran yang hendak dicapai. Bagian isi terdiri dari fenomena, kegiatan eksperimen, uraian materi, penerapan konsep, diskusi konseptual, contoh soal, rangkuman, dan uji kompetensi. Isi modul memuat 3 Kegiatan Belajar (KB). KB 1 membahas tekanan dan tekanan hidrostatis, KB 2 membahas hukum Pascal dan hukum Archimedes, dan KB 3 membahasa tegangan permukaan dan kapilaritas. Untuk masing-masing KB di dalamnya memuat sintaks model pembelajaran Learning Cycle 5E dengan memunculkan pula karakteristik kemampuan berpikir analitis. Bagian penutup berisi refleksi, evaluasi, daftar pustaka, dan glosarium.
Setiap kegiatan belajar terdiri dari 5 rubrik, yaitu "Fenomena", "Ayo Kita Selidiki", "Pemantapan Konsep", "Penerapan", dan "Uji Kompetensi". Setiap rubrik disesuaikan dengan sintaks model pembelajaran berbasis Learning Cycle 5E. Rubrik "Fenomena" berisi orientasi masalah yang dapat siswa temui dalam kehidupan sehari-hari yang bertujuan untuk mengukur kemampuan menginterpretasi informasi dan ide. Rubrik “Ayo Kita Selidiki” berisi arahan bagi siswa untuk berkelompok dan menjawab permasalahan awal melalui kegiatan praktikum. Rubrik ini berfungsi untuk mengukur kemampuan penggunaan konsep untuk memecahkan permasalahan. Rubrik "Pemantapan Konsep" berisi tentang uraian materi untuk memantapkan konsep yang sebelumnya di dapat siswa melalui praktikum. Siswa juga diarahkan untuk berdiskusi menjawab permasalahan awal berdasarkan hasil penyelidikan dan pemantapan konsep. Tujuan dari rubrik ini adalah untuk memunculkan kemampuan siswa membuat dan mengevaluasi kesimpulan umum berdasarkan penyelidikan. Rubrik selanjutnya adalah "Penerapan". Pada rubrik ini selain siswa disajikan beberapa contoh penerapan konsep dalam keseharian, siswa juga diajak untuk menuliskan analisisnya mengenai konsep yang bekerja pada contoh-contoh lain. Selain itu siswa juga diajak untuk berdiskusi menyelesaikan permasalahan konseptual. Rubrik ini bertujuan untuk mengarahkan siswa memberikan alasan mengapa sebuah jawaban suatu masalah adalah masuk akal dan menggunakan konsep yang telah diketahuinya dalam pemecahan permasalahan. Rubrik terakhir adalah "Uji Kompetensi" rubrik ini bertujuan untuk mengukur kemampuan penggunaan konsep yang didapatkan siswa untuk memecahkan permasalahan dan untuk melatihkan kemampuan siswa memberikan alasan 
INKUIRI: Jurnal Pendidikan IPA

Vol. 8, No. 1, 2019 (hal 94-109)

https://jurnal.uns.ac.id/inkuiri

mengapa sebuah jawaban suatu masalah adalah masuk akal.

Jenis modul yang dikembangkan adalah modul cetak fisika berbasis Learning Cycle 5E yang bertujuan untuk meningkatkan kemampuan berpikir analitis. Modul fisika berbasis Learning Cycle 5E dibuat sebagai buku pegangan siswa untuk belajar mandiri, dapat dilakukan di rumah tanpa harus melakukannya di sekolah. Sehingga diharapkan pembelajaran akan lebih bermakna dan dapat melatih sekaligus meningkatkan kemampuan berpikir analitis siswa. Hasil penelitian Indrianto (2014) menguatkan bahwa penggunaan modul fisika efektif untuk melatihkan kemampuan berpikir analitis siswa. Selain itu hasil penelitian Rizal (2013) juga menguatkan bahwa kemampuan berpikir analitis siswa dapat meningkat setelah melalui proses pembelajaran berbasis Learning Cycle 5E.

\section{Tahap Pengembangan (Develop)}

Tahapan Develop ini diawali dengan validasi draft 1 modul fisika berbasis Learning Cycle 5E yang dilakukan oleh validator ahli, guru fisika dan teman sejawat yang selanjutnya direvisi dan diujicobakan ke kelompok kecil dan kelompok besar.

Validasi dilakukan oleh tiga validator ahli, dua guru fisika (reviewer) dan dua teman sejawat (peer reviewer). Komponen penilaian modul untuk setiap validator berbeda-beda disesuaikan dengan tujuan validasi modul. Instrumen penilaian kelayakan modul dari segi materi terdiri dari 3 aspek yaitu aspek pembelajaran, aspek materi, dan aspek pembelajaran berbasis Learning Cycle 5E dalam modul. Skor rata-rata yang diperoleh dari ketiga komponen penilaian kelayakan modul dari segi materi adalah 3,32 dengan kategori "Sangat Baik". Instrumen penilaian kelayakan media terdiri dari 3 komponen yang diuraikan ke dalam 7 sub komponen yaitu ukuran fisik modul,
P-ISSN: 2252-7893

DOI: 10.20961/inkuiri.v8i1.31824

tata letak kulit modul, tipografi kulit modul, ilustrasi kulit modul, tata letak isi modul, tipografi isi modul, dan ilustrasi isi modul. Hasil analisis penilaian kelayakan media rata-rata secara kesuluran diperoleh skor sebesar 3,78 dalam kategori "Sangat Baik". Penilaian kelayakan bahasa memuat 5 komponen yaitu bahasa yang digunakan sesuai dengan tingkat perkembangan peserta didik, komunikatif, lugas, sesuai dengan kaidah Bahasa Indonesia, dan kesesuaian penggunaan istilah dan simbol/ lambang. Hasil analisis penilaian kelayakan bahasa diperoleh rata-rata nilai keseluruhan sebesar 3,35 dengan kategori "Sangat Baik". Penilaian kelayakan modul oleh praktisi guru (reviewer) dan oleh teman sejawat (peer reviewer) mencakup lima komponen yaitu kelayakan isi, penyajian, bahasa dan keterbacaan, kegrafisan, dan kesesuaian konten modul dengan tahapan pembelajaran berbasis Learning Cycle 5E dalam modul. Berdasarkan hasil penilaian dari reviewer modul dapat dikategorikan sangat baik dengan rata-rata nilai keseluruhan sebesar 3,50. Sedangkan penilaian oleh peer reviewer memperoleh rata-rata nilai sebesar 3,51 dengan kategori "Sangat Baik". Selanjutnya hasil penilaian kelayakan modul secara keseluruhan dihitung dengan menggunakan analisis Cut Off dan didapatkan nilai natural Cut Off sebesar 87,32 dan skor rata-rata modul 88,74 . Sehingga dapat disimpulkan bahwa modul fisika berbasis Learning Cycle 5E yang dikembangkan "Layak" diimplementasikan dalam pembelajaran fisika.

Adapun beberapa saran dari validator disajikan pada Tabel 1 .

\begin{tabular}{|c|c|}
\hline Saran & Revisi I \\
\hline $\begin{array}{l}\text { Penulisan bahasa asing } \\
\text { harus konsisten dicetak } \\
\text { miring }\end{array}$ & $\begin{array}{l}\text { Penulisan bahasa asing } \\
\text { sudah diganti dengan cetak } \\
\text { miring }\end{array}$ \\
\hline $\begin{array}{l}\text { Penulisan simbol }(V) \text { untuk } \\
\text { volum, harus ditulis }\end{array}$ & $\begin{array}{l}\text { Semua penulisan simbol } \\
(V) \text { untuk volum sudah }\end{array}$ \\
\hline
\end{tabular}




\begin{tabular}{ll}
\hline Saran & \multicolumn{2}{c}{ Revisi I } \\
\hline $\begin{array}{l}\text { konsisten dengan huruf } \\
\text { capital dicetak miring }\end{array}$ & $\begin{array}{l}\text { diganti dengan huruf } \\
\text { capital dicetak miring }\end{array}$ \\
\hline $\begin{array}{l}\text { Halaman francis dibuat } \\
\text { tanpa background cover } \\
\text { (polos) }\end{array}$ & $\begin{array}{l}\text { Halaman francis sudah } \\
\text { dibuat polos }\end{array}$ \\
\hline $\begin{array}{l}\text { Pembuatan peta konsep } \\
\text { didasarkan pada teori }\end{array}$ & $\begin{array}{l}\text { Peta konsep sudah } \\
\text { diperbaiki dan dibuat } \\
\text { berdasarkan teori Novak }\end{array}$ \\
\hline $\begin{array}{l}\text { Setiap gambar dilengkapi } \\
\text { dengan sumber acuan }\end{array}$ & $\begin{array}{l}\text { Setiap gambar yang tidak } \\
\text { dibuat sendiri (didapatkan } \\
\text { dari buku dan internet) } \\
\text { sudah dilengkapi dengan }\end{array}$ \\
\hline $\begin{array}{l}\text { Keajegan penomeran } \\
\text { rincian/ uraian masih perlu } \\
\text { perbaikan }\end{array}$ & $\begin{array}{l}\text { Keajegan sudah diperbaiki sesuai } \\
\text { suluran penulisan yang tepat }\end{array}$ \\
\hline $\begin{array}{l}\text { Konsistensi penggunaan } \\
\text { kalimat perintah pada } \\
\text { langkah percobaan perlu } \\
\text { diperbaiki }\end{array}$ & $\begin{array}{l}\text { Kalimat yang digunakan } \\
\text { pada langkah percobaan } \\
\text { sudah diperbaiki dengan } \\
\text { menggunakan } \\
\text { perintah semua kalimat }\end{array}$ \\
\hline $\begin{array}{l}\text { Penulisan simbol dalam } \\
\text { persamaan, gambar, dan } \\
\text { paragraf harus konsisten }\end{array}$ & $\begin{array}{l}\text { Penulisan simbol dalam } \\
\text { persamaan, gambar, dan } \\
\text { paragraf sudah diperbaiki }\end{array}$ \\
\hline
\end{tabular}

Setelah draf I direvisi dihasilkan draf II berdasarkan masukan dan saran dari validator. Draf II selanjutnya diujicobakan terbatas kepada 12 siswa kelas XII SMA Negeri 2 Ngawi. Tahap ini bertujuan untuk mendapatkan penilaian keterbacaan modul, saran, dan tanggapan dari siswa terhadap modul yang dikembangkan. Skor rata-rata penilaian modul yang diperoleh dari tahap uji coba terbatas ini sebesar 3,36 dengan kategori "Sangat Baik". Adapun beberapa saran dari siswa yaitu:

\begin{tabular}{|c|c|}
\hline Saran & Revisi II \\
\hline $\begin{array}{l}\text { Ada beberapa gambar di } \\
\text { dalam modul yang kurang } \\
\text { jelas/ pecah }\end{array}$ & $\begin{array}{llr}\text { Gambar } & \text { sudah diganti } \\
\text { dengan resolusi } & \text { yang } \\
\text { lebih baik } & & \\
\end{array}$ \\
\hline $\begin{array}{l}\text { Pada langkah percobaan } 2.1 \\
\text { keterangan ukuran suntikan } \\
\text { yang digunakan tidak sama, } \\
\text { pada alat dan bahan } \\
\text { digunakan ukuran } 20 \mathrm{ml} \\
\text { sedangkan pada langkah } \\
\text { percobaan ukurannya } 30 \mathrm{ml}\end{array}$ & $\begin{array}{lr}\text { Kesalahan } & \text { penulisan, } \\
\text { pada langkah } & \text { percobaan } \\
\text { sudah } & \text { diperbaiki } \\
\text { menggunakan } & \text { suntikan } \\
\text { berukuran } 20 \mathrm{ml} \text { (Gambar } \\
\text { 4.5) }\end{array}$ \\
\hline $\begin{array}{l}\text { Keterangan pada soal } \\
\text { (halaman 72) dan gambar } \\
\text { tidak sama, pada soal tertulis } \\
5000 \mathrm{~kg} \text { sedangkan pada } \\
\text { gambar tertulis } 500 \mathrm{~kg}\end{array}$ & $\begin{array}{l}\text { Kesalahan penulisan, } \\
\text { keterangan pada soal } \\
\text { sudah diganti } 500 \mathrm{~kg}\end{array}$ \\
\hline $\begin{array}{l}\text { Ada penulisan keterangan } \\
\text { pada gambar yang kurang } \\
\text { jelas (halaman 57) }\end{array}$ & $\begin{array}{l}\text { Penulisan keterangan } \\
\text { pada gambar sudah } \\
\text { diperbaiki }\end{array}$ \\
\hline
\end{tabular}

Draf II modul yang sudah diperbaiki selanjutnya menghasilkan draf III modul yang digunakan pada uji coba skala besar pada 32 siswa kelas XI SMA. Data yang diperoleh pada uji coba skala besar adalah data kemampuan berpikir analitis, hasil belajar, dan respon siswa terhadap modul.

Kemampuan berpikir analitis diukur sebelum siswa menggunakan modul (pre-test) dan sesudah siswa menggunakan modul (post-test). Data kemampuan berpikir analitis terlebih dahulu dianalisis normalitas dan homogenitasnya. Hasil analisis statistik menunjukkan bahwa data terdistribusi normal dan variansinya homogen baik data pre-test maupun post-test. Selanjutnya data dianalisis menggunakan statistik parametrik untuk melihat ada atau tidaknya perbedaan rata-rata skor pre-test dan post-test. Dari hasil analisis diperoleh kesimpulan bahwa terdapat perbedaan kemampuan berpikir analitis sebelum dan sesudah menggunakan modul yang dikembangkan. Perbedaan rata-rata antara pre-test dan post-test selanjutnya dihitung peningkatannya melalui $N$-Gain score seperti pada Tabel 3.

Tabel 3. Hasil Penilaian Kemampuan Berpikir Analitis Setiap Indikator

\begin{tabular}{|c|c|c|c|c|}
\hline \multirow{2}{*}{ No. } & \multirow{2}{*}{ Indikator } & \multicolumn{2}{|c|}{ Ketercapaian } & \multirow{2}{*}{$\begin{array}{c}N- \\
\text { Gain }\end{array}$} \\
\hline & & Pre-test & $\begin{array}{c}\text { Post- } \\
\text { test }\end{array}$ & \\
\hline 1 & Interpretasi & 0.43 & 0.66 & 0.41 \\
\hline 2 & $\begin{array}{l}\text { Menggunakan } \\
\text { Konsep }\end{array}$ & 0.52 & 0.77 & 0,52 \\
\hline 3 & $\begin{array}{l}\text { Membuat } \\
\text { Evaluasi }\end{array}$ & 0.44 & 0.61 & 0.31 \\
\hline 4 & $\begin{array}{c}\text { Memberikan } \\
\text { Alasan }\end{array}$ & 0.47 & 0.70 & 0.43 \\
\hline & Rata-Rata & 0.46 & 0.69 & \\
\hline & $N$-Gain & & 0.41 & \\
\hline
\end{tabular}

Tabel 3 menunjukkan skor kemampuan berpikir analitis siswa pada tiap indikator. Peningkatan paling tinggi ada pada indikator menggunakan konsep dalam pemecahan masalah yang meningkat sebesar 0,52 dengan kategori 
INKUIRI: Jurnal Pendidikan IPA

Vol. 8, No. 1, 2019 (hal 94-109)

https://jurnal.uns.ac.id/inkuiri

"Sedang". Kemampuan penggunaan konsep mengalami peningkatan yang paling tinggi disebabkan karena pada modul yang dikembangkan kemampuan analitis ini dikaitkan dengan tahapan explore. Pada tahapan explore ini siswa diarahkan untuk menyelidiki permasalahan melalui percobaan mandiri dan berdiskusi menjawab permasalahan melalui analisis data percobaan. Dari tahapan Learning Cycle 5E ini tampak bahwa kegiatan siswa pada tahap ini penuh dengan kegiatan ilmiah, menyelidiki dan menganalisis. Adanya kegiatan ilmiah dapat membangkitkan kemampuan berpikir analitis siswa (Susanti, 2012). Inilah yang menjadi penyebab kemampuan berpikir analitis siswa mengalami kenaikan yang paling tinggi dalam tahap ini. Kemampuan menginterpretasi informasi dan ide, serta kemampuan memberikan alasan juga meningkat dalam kriteria sedang dengan peningkatan berturut-turut sebesar 0,41 dan 0,43. Kemampuan membuat evaluasi mengalami peningkatan yang paling rendah apabila dibandingkan dengan kemampuan lainnya. Besar peningkatannya adalah 0,31 dengan kategori "Sedang". Kemampuan membuat dan mengevaluasi kesimpulan umum mengalami peningkatan yang paling rendah karena kurangnya bagian modul pada tahap explain dan evaluate yang melatihkan kemampuan ini. Pada tahap explain, dalam modul siswa hanya diarahkan untuk membuat kesimpulan umum berdasarkan percobaan dan diskusi bersama yang dilakukan. Hanya satu kegiatan analisis ini menyebabkan kemampuan siswa untuk membuat dan mengevaluasi kesimpulan umum kurang terlatih. Pada tahap evaluate, sebenarnya siswa sudah diberikan beberapa soal untuk melatihkan kemampuan ini, tapi karena kurangnya waktu untuk membahas dan ditemukan juga beberapa siswa tidak mengerjakan soal yang diberikan secara mandiri maka
P-ISSN: 2252-7893

E-ISSN: 2615-7489

DOI: 10.20961/inkuiri.v8i1.31824

kemampuan ini bisa dikatakan kurang terlatih. Selain itu pada tahap ini kurang dilakukan kegiatan ilmiah, seperti mengamati, menganalisis, dan berdiskusi. Namun secara keseluruhan kemampuan berpikir analitis siswa meningkat sebesar 0,41 dengan kategori "Sedang". Sehingga dapat disimpulkan bahwa penggunaan modul fisika berbasis Learning Cycle 5E efektif untuk meningkatkan kemampuan berpikir analitis siswa. Hasil penilitian ini sejalan dengan hasil penelitian yang pernah dilakukan oleh Rizal (2013) yang menyatakan bahwa pembelajaran sains dengan menggunakan model pembelajaran berbasis Learning Cycle 5E dapat meningkatkan kemampuan berpikir analitis siswa. Hal ini diperkuat oleh Susanti (2012) yang menyatakan bahwa pengajaran berdasarkan siklus belajar (Learning Cycle) 5E merupakan pendekatan yang efektif untuk mengajarkan proses berpikir analitis.

Implementasi modul pembelajaran fisika berbasis Learning Cycle 5E dikatakan efektif meningkatkan hasil belajar siswa apabila tercapainya Kriteria Ketuntasan Minimum (KKM) sebesar 75 dengan persentase ketuntasan sebesar $75 \%$. Hasil belajar ranah kognitif diperoleh dari nilai tes yang terdiri dari 20 soal pilihan ganda. Kisi-kisi soal kognitif yang digunakan mengacu pada taksonomi Bloom yang terdiri dari 6 tingkatan, yaitu $\mathrm{C} 1$ (pengetahuan), $\mathrm{C} 2$ (pemahaman), $\mathrm{C} 3$ (penerapan), $\mathrm{C} 4$ (analisis), C5 (sintesis), dan C6 (evaluasi). Tes ranah kognitif dilaksanakan sesudah siswa selesai menggunakan modul fisika. Dari hasil tes didapatkan nilai rata-rata siswa pada hasil belajar ranah kognitif mencapai 78,28 yang berarti bahwa implementasi modul fisika berbasis Learning Cycle 5E membantu siswa untuk mencapai KKM ranah kognitif dengan persentase ketuntasan sebesar $87,50 \%$ diatas $75 \%$. Sehingga dapat disimpulkan bahwa 
implementasi modul pembelajaran fisika berbasis Learning Cycle 5E efektif untuk mencapai standar ketuntasan hasil belajar kognitif. Hasil ini relevan dengan penelitian yang dilakukan oleh Utari (2013) yang menyatakan bahwa penggunaan media berbasis Learning Cycle 5E efektif meningkatkan kemampuan kognitif siswa.

Hasil belajar ranah afektif dinilai pada setiap berlangsungnya Kegiatan Belajar (KB). Penilaian ranah afektif pada penelitian ini dilakukan oleh dua orang observer. Adapun indikator penilaian ranah afektif meliputi aspek disiplin, jujur, bertanggungjawab, bekerja sama, menyampaiakan pendapat, dan menanggapi pendapat. Analisis penilaian hasil belajar ranah afektif ditunjukkan pada Gambar 1.

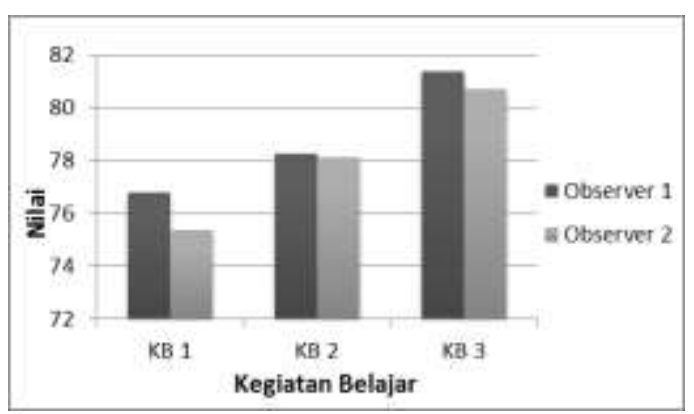

Gambar 1. Hasil Penilaian Ranah Afektif Siswa

Data yang tampak pada Gambar 1 menunjukkan bahwa nilai rata-rata siswa pada KB 1 hingga KB 3 terus meningkat, jika dibandingkan dengan nilai KKM sebesar 75. Dengan persentase ketuntasan berturut-turut $77,78 \%$; 81,24\%; dan $81,48 \%$ berada di atas $75 \%$. Aspek-aspek ranah afektif muncul ketika siswa sedang berdiskusi bersama temannya dan ketika siswa melakukan percobaan. Petunjuk pada modul berbasis Learning Cycle 5E yang mengedepankan pada penemuan konsep oleh siswa secara mandiri ternyata efektif untuk meningkatkan hasil belajar siswa ranah afektif. Dengan menggunakan modul ini siswa diarahkan untuk melakukan percobaan, menganalisis, dan berdiskusi.
Berdasarkan hasil tersebut, dapat dikatakan bahwa modul fisika berbasis Learning Cycle 5E efektif untuk mencapai standar ketentuan hasil belajar afektif. Hasil ini relevan dengan hasil penelitian yang dilakukan oleh oleh Susanti (2012) yang menyatakan bahwa penggunaan basis pembelajaran Learning Cycle 5E berpengaruh positif pada peningkatan hasil belajar siswa pada ranah afektif.

Penilaian ranah psikomotor dilakukan selama pembelajaran berlangsung dengan menggunakan lembar observasi oleh 2 orang observer. Adapun indikator penilaian ranah psikomotor meliputi menyiapkan alat dan bahan percobaan, mengoperasikan alat percobaan dengan benar, mengambil data dengan teliti, serta merapikan alat dan bahan setelah selesai kegiatan percobaan. Hasil penilaian ranah psikomotor dapat dilihat pada Gambar 2.

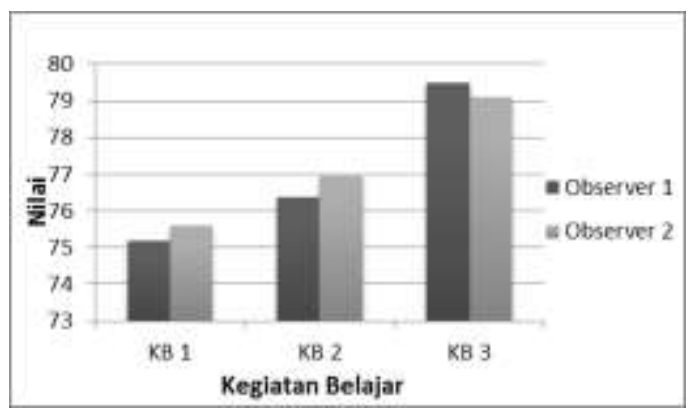

Gambar 2. Hasil Penilaian Ranah Psikomotor

Adanya kegiatan percobaan membuat kemampuan belajar siswa ranah psikomotor meningkat. Tampak dari data observasi yang dilakukan oleh 2 orang observer didapatkan nilai hasil belajar siswa ranah psikomotor konsisten mengalami kenaikan lebih tinggi dibandingkan dengan KKM sebesar 75. Selain itu didapatkan pula persentase ketuntasan belajar psikomotor pada setiap pertemuan lebih tinggi dari standar ketuntasan 75\%, persentasenya berturut-turut adalah $76,56 \%, 79,49 \%$, dan $81,25 \%$. Sehingga disimpulkan bahwa penggunaan modul fisika berbasis Learning Cycle 5E efektif 
untuk mencapai standar ketuntasan hasil belajar ranah psikomotor.

Berdasarkan uraian mengenai efektivitas penggunaan modul yang sedang dikembangkan terhadap hasil belajar ranah kognitif, afektif, dan psikomotor didapatkan kesimpulan bahwa modul fisika berbasis Learning Cycle 5E efektif dalam ketercapaian ketuntasan hasil belajar siswa.

Modul yang telah diujikan dalam skala besar selanjutnya akan dinilai oleh siswa melalui pengisian angket respon. Ada empat aspek yang harus dinilai oleh siswa yaitu aspek perhatian (attention), keterkaitan (relevance), keyakinan (confidence), dan kepuasan (satisfication). Secara keseluruhan didapatkan respon siswa tergolong dalam kategori "Sangat Baik" dengan skor rata-rata sebesar $80,62 \%$. Saran dan komentar siswa mengenai modul dapat dilihat pada Tabel 4.

Tabel 4. Saran dan Perbaikan Modul Uji Skala Besar

\begin{tabular}{|c|c|}
\hline Saran & Revisi III \\
\hline $\begin{array}{l}\text { Ada beberapa penulisan } \\
\text { yang salah ketik }\end{array}$ & $\begin{array}{l}\text { Kesalahan penulisan } \\
\text { sudah diperbaiki }\end{array}$ \\
\hline $\begin{array}{l}\text { Beberapa gambar kurang } \\
\text { jelas/ pecah }\end{array}$ & $\begin{array}{l}\text { Kualitas gambar sudah } \\
\text { diperbaiki }\end{array}$ \\
\hline
\end{tabular}

Selain memberikan saran, siswa juga memberikan pendapatnya mengenai modul yang sedang dikembangkan. Dari angket respon yang telah disebar, didapatkan tanggapan bahwa dengan adanya modul yang dikembangkan, siswa merasa terbantu dalam memahami materi. Dari segi tampilan siswa merasa modul yang dikembangkan menarik dan tidak membosankan, serta cocok digunakan untuk bahan ajar. Dari beberapa aspek tersebut, dapat disimpulkan bahwa siswa merespon dengan baik modul yang sedang dikembangkan berdasarkan tampilannya yang menarik, kemudahan memahami materi dan meningkatkan minat siswa belajar siswa.

\section{Tahap Penyebaran (Disseminate)}

Penyebaran modul dilakukan di 5 sekolah yaitu SMA Islam 1 Surakarta, SMA Muhammadiyah 6 Surakarta, SMA Muhammadiyah 1 Surakarta, SMA 1 Karangjati Ngawi, dan SMA Ma'arif Ngawi. Modul diberikan kepada salah satu guru di sekolah-sekolah tersebut, selanjutnya guru mengisi angket penilaian produk. Berdasarkan penilaian produk akhir didapatkan bahwa modul yang dikembangkan mendapatkan skor rata-rata 3,36 dengan konversi nilai sebesar $84,00 \%$ termasuk dalam kategori "Sangat Baik". Menurut Waluyo (2015) jika hasil respon guru pada kategori "Sangat Baik" menunjukkan bahwa modul layak untuk digunakan sebagai salah satu media pembelajaran. Saran dan masukan pada tahap ini dijadikan sebagai umpan balik untuk menghasilkan produk yang lebih baik di penelitian selanjutnya.

\section{Kesimpulan dan Rekomendasi}

\section{Kesimpulan}

Kesimpulan dari hasil penelitian pengembangan modul fisika berbasis Learning Cycle 5E yang telah dilakukan adalah:

1. Karakteristik modul fisika yang dikembangkan berupa modul cetak materi fluida statis yang berbasis Learning Cycle 5E dengan tahapan engage, explore, explain, elaborate, dan evaluate dengan memunculkan kemampuan berpikir analitis dalam setiap tahapannya yaitu menginterpretasi informasi, menggunakan konsep dalam pemecahan masalah, membuat dan mengevaluasi kesimpulan, serta memberikan alasan setiap jawaban adalah masuk akal.

2. Modul fisika berbasis Learning Cycle $5 \mathrm{E}$ pada materi fluida statis divalidasi oleh validator ahli materi, ahli media, ahli bahasa, guru fisika, dan teman sejawat. Hasil rata-rata uji kelayakan menggunakan metode cut off score 
adalah sebesar $87,32 \%$ dan skor ratarata $88,74 \%$. Didapatkan pula hasil analisis respon guru pada tahap penyebaran dengan nilai rata-rata sebesar 84,00\% masuk dalam kategori "Sangat Baik". Sedangkan berdasarkan hasil analisis angket respon modul oleh siswa yang didapatkan respon sangat baik dengan skor rata-rata sebesar 80,62\%. Dari hasil tersebut dapat disimpulkan bahwa modul fisika berbasis Learning Cycle 5E yang dikembangkan layak digunakan sebagai bahan ajar dalam pembelajaran fisika.

3. Efektivitas dari implementasi modul fisika berbasis Learning Cycle $5 \mathrm{E}$ dilihat berdasarkan adanya peningkatan kemampuan berpikir analitis serta ketercapaian ketuntasan pada hasil belajar siswa. Hasil perhitungan nilai $N$-Gain untuk peningkatan kemampuan berpikir analitis siswa sebesar 0,41 dengan kategori "Sedang". Indikator kemampuan berpikir analitis siswa yang paling meningkat adalah kemampuan menggunakan konsep yang telah diketahui dalam pemecahan permasalahan. Selain itu penggunaan modul fisika berbasis Learning Cycle 5E juga terbukti efektif dalam pencapaian ketuntasan hasil belajar siswa ranah kognitif, afektif, dan psikomotor. Berdasarkan hasil ini dapat dikatakan bahwa implementasi modul pembelajaran fisika berbasis Learning Cycle 5E efektif untuk meningkatkan kemampuan berpikir analitis dan efektif pula dalam mencapai standar ketuntasan hasil belajar siswa.

\section{Rekomendasi}

1. Modul fisika berbasis Learning Cycle 5E yang telah dikembangkan dapat dijadikan sebagai rujukan untuk mengembangkan modul pada materi lain dengan mempertimbangkan karakteristik dan kebutuhan siswa.

2. Sebaiknya gurur memahami penerapan sintaks model pembelajaran berbasis Learning Cycle 5E agar tujuan modul untuk meningkatkan kemampuan berpikir analitis siswa dapat tercapai.

3. Kekurangan dan ketidaksempurnaan produk yang telah dihasilkan sebaiknya dijadikan sebagai wawasan untuk menciptakan produk yang lebih baik.

\section{Daftar Pustaka}

Areesophonpichet, Sornate. (2013). A Development of Analytical Thinking Skills of Graduate Students by using Concept Mapping, hlm 1-15. The Asian Conference on Education 2013. Chulalongkorn University, Thailand.

Bybee, Rodger. W. (2009). The BSCS 5E Instructional Model and $21^{\text {st }}$ Century Skills. The National Academies Board on Science Education.

Campbell, Meghann. (2006). The Effects of The 5E Learning Cycle Model on Students' Understanding of Force and Motion Concepts. Master Thesis. Florida: University of Central Florida.

Dahar, Ratna Wilis. (1989). Teori-Teori Belajar. Jakarta: Erlangga.

Depdiknas. (2008). Teknik Penyusunan Modul. Jakarta: Direktorat Jenderal Manajemen Pendidikan Dasar Menengah, Departemen Pendidikan Nasional.

Erniningsih. (2012). Pembelajaran Biologi Model PBM Menggunakan Lembar Kerja Terbimbing dan Lembar Kerja Bebas Termodifikasi Ditinjau dari Keterampilan Proses Sains dan Kemampuan Berpikir Analitis. Tesis. Surakarta: Universitas Sebelas Maret. 
Indrianto, Sulis. (2014). Pengembangan Modul Inkuiri Terbimbing untuk Meningkatkan Kemampuan Berpikir Analitis pada Materi Ajar Struktur dan Fungsi Jaringan Tumbuhan pada Kelas VIII SMP 22 Surakarta. Tesis. Surakarta: Universitas Sebelas Maret.

Jauhariyah, Niswati. (2013). Pengembangan Modul Fisika Berbasis Problem Based Learning pada Materi Fluida untuk Siswa Cerdas Istimewa Berbakat Istimewa (CIBI). Tesis. Surakarta: Universitas Sebelas Maret.

Misman. (2013). Pembelajaran Fisika Menggunakan Model Siklus Belajar (Learning Cycle) $5 E$ dengan Metode Eksperimen dan Demonstrasi Ditinjau dari Kreativitas dan Sikap ilmiah Siswa. Tesis. Surakarta: Universitas Sebelas Maret.

Prastowo, Andi. (2013). Pengembangan Bahan Ajar Tematik. Jogjakarta: DIVA Press.

Permatasari, Indhah. (2015). Pengembangan Modul Fisika Berbasis Siklus Belajar 7E Berbantuan Video pada Materi Fluida Dinamis Sebagai Upaya untuk Meningkatkan Motivasi Belajar Siswa Kelas XI. Tesis. Surakarta: Universitas Sebelas Maret.

Rizal. (2013). Pembelajaran Kimia Menggunakan Metode Inkuiri Terbimbing dan Siklus Belajar 5E Ditinjau dari Kemampuan Analisis dan Kemampuan Matematis. Tesis. Surakarta: Universitas Sebelas Maret.

Septiani, Winnie. (2009). Pendekatan Kombinasi Metode AHP dan Metode Cut Off Point pada Tahap Analisis Keputusan Perancangan Sistem Informasi Penjualan PT.X. J@TI Undip, Vol IV (3), 218-227.

Suparno, Paul. (2007). Metode Penelitian Pendidikan Fisika. Yogyakarta: Universitas Sanata Dharma.
(2013).

Pembelajaran

Metodologi

Konstruktivistik \& Menyenangkan.

Yogyakarta: Universitas Sanata Dharma.

Susanti, Rini. (2012). Pembelajaran Kimia Menggunakan Siklus Belajar 5E dan Inkuiri Bebas Termodifikasi Ditinjau dari Kemampuan Berpikir Analisis dan Kreativitas Siswa. Tesis. Surakarta: Universitas Sebelas Maret.

Taufiq. (2010). Pengembangan Modul Berbasis Siklus Belajar Hipotetikal Deduktif untuk Meningkatkan Pemahaman Konsep dan Keterampilan Generik Sains pada Materi Kesetimbangan Benda Tegar. Bandung: UPI Press.

Thaneerananon, Taveep. (2016). Development of a Test to Evaluate Students' Analytical Thinking Based on Fact versus Opinion Differentiiation. International Journal of Instruction, vol.9, no.2, hlm 123-138.

Thiagarajan, Sivasailam, DS, \& Melvyn, S. (1974). Instruction Development for Training Teacher of Exceptional children. Minneapolis: Indian University.

Utari, Setiya. (2013). Application of Learning Cycle 5E Model Aided Cmaptools-Based Media Prototype to Improve Student Cognitif Learning Outcomes. The Canadian Center of Science and Education Journal, vol. 5, No. 4, hlm. 69-76.

Waluyo, Sugeng. (2015). Pengembangan Modul Berbasis Guided Discovery pada Materi Jamur untuk Meningkatkan Kemampuan Berpikir Analitis Siswa SMAN 1 Bulu. Tesis. Surakarta Universitas Sebelas Maret.

Zulfah, Hadaina. (2015). Penerapan Model Pembelajaran Inquiry Learning dipadu Jurnal Belajar Reflektif untuk Meningkatkan Kemampuan Berpikir Analitis pada Siswa Kelas XI MIA 3 SMA Negeri 7 Surakarta. 
INKUIRI: Jurnal Pendidikan IPA

P-ISSN : 2252-7893

Vol. 8, No. 1, 2019 (hal 94-109)

E-ISSN: 2615-7489

https://jurnal.uns.ac.id/inkuiri

Tesis. Surakarta Universitas

Sebelas Maret. 